\title{
GAMBARAN MIKROSKOPIK GINJAL TIKUS WISTAR (RATTUS NORVEGICUS) SETELAH DIINDUKSI DENGAN GENTAMISIN
}

\author{
Poppy M. Lintong \\ Carla F. Kairupan \\ Priska L. N. Sondakh
}

\begin{abstract}
Bagian Patologi Anatomi Fakultas Kedokteran Universitas Sam Ratulangi Manado Email: magda_plin@yahoo.com
\end{abstract}

\begin{abstract}
Gentamycin, a frequently used aminoglycoside antibiotics, has a nephrotoxic effect to human beings and animals. The purpose of this research was to find out the microscopic changes of wistar rat kidneys after gentamycin induction. This was an experimental study, using five adult wistar rats, divided into three groups. Group I was the control group; group II consisted of two rats, injected with gentamycin $0,3 \mathrm{ml} / \mathrm{day}$ (dose of $60 \mathrm{mg} / \mathrm{kg}$ body weight/day) intraperitoneally for seven days; and group III consisted of two rats, injected with gentamycin $0,3 \mathrm{ml} /$ day intraperitoneally for 10 days. Group I and II were terminated at day- 8 , and group III at day-11. Their kidneys were processed for microscopic slides, stained with hematoxylin eosin and Periodic Acid Schiff. In microscopic evaluation, group II and III showed oedema, necrosis, apoptosis, and basal membrane destruction of tubular epithelial cells. Group III also showed fat vacuoles in these epithelial cells (macrovesicular fatty changes). Conclusion: wistar rats injected with gentamycin $60 \mathrm{mg} / \mathrm{kg}$ body weight/day for 7 and 10 days showed oedema, necrosis, apoptosis, and basal membrane destruction of tubular epithelial cells; and macrovesicular fatty changes after 10 days of gentamycin.
\end{abstract}

Key words: gentamycin, necrosis tubular epithelial cells, fatty changes

\begin{abstract}
Abstrak: Gentamisin termasuk antibiotik golongan aminoglikosida berspektrum luas yang bersifat nefrotoksik terhadap manusia dan hewan. Tujuan penelitian ini untuk melihat perubahan mikroskopik struktur ginjal tikus Wistar setelah diberikan gentamisin. Metode penelitian eksperimental dengan menggunakan lima ekor tikus Wistar dewasa yang dibagi atas tiga kelompok. Kelompok I tanpa perlakuan; kelompok II terdiri dari dua ekor tikus perlakuan yang diinjeksi dengan gentamisin $0,3 \mathrm{ml} / \mathrm{hari}$ (dosis $60 \mathrm{mg} / \mathrm{kgBB} / \mathrm{hari}$ ) secara intraperitonial selama tujuh hari; dan kelompok III terdiri dari dua ekor tikus perlakuan yang diinjeksi dengan gentamisin $0,3 \mathrm{ml} /$ hari secara intraperitonial selama 10 hari. Tikus Wistar kelompok I dan II diteminasi hari ke-8, sedangkan kelompok III diterminasi hari ke-11. Ginjal tikus kelompok I -III kemudian dibuat preparat histopatologik dengan pengecatan rutin hematoksilin eosin dan Periodic Acid Schiff (PAS). Hasil penelitian menunjukkan tikus Wistar perlakuan yang diberikan gentamisin $0,3 \mathrm{ml} / \mathrm{hari}$ selama 7 sampai 10 hari secara mikroskopik memperlihatkan pembengkakan, nekrosis, apoptosis, dan destruksi membrana basalis sel epitel tubulus; dan pada hari ke-10 terlihat vakuol-vakuol lemak pada sel epitel sehingga inti terdesak ke tepi (perlemakan makrovesikuler). Simpulan: pemberian gentamisin pada tikus Wistar dengan dosis $60 \mathrm{mg} / \mathrm{kg}$ BB/hari selama 7-10 hari menunjukkan pembengkakan, nekrosis, apoptosis sel epitel tubulus, dan membrana basalis tubulus rusak; dan setelah hari ke-10 juga terlihat perlemakan makrovesikuler.
\end{abstract}

Kata kunci: gentamisin, nekrosis sel epitel tubulus, perlemakan makrovesikuler 
Gentamisin merupakan antibiotika turunan aminoglikosida yang berefek nefrotoksik, neurotoksik terhadap saraf otak, dan ototoksik terhadap komponen vestibular maupun akustik. Efek antibakteri dari antibiotik turunan aminoglikosida seperti gentamisin terutama ditujukan pada basil gram negatip aerobik. Transpor aminoglikosida memerlukan oksigen sebagai transport aktif. ${ }^{1-3}$

Pemberian secara oral hanya diabsorpsi sedikit pada saluran pencernaan, sisanya diekskresi ke dalam feses. Aminoglikosida juga dapat diserap bila terdapat ulserasi pada usus. Pemberian aminoglikosida secara intramuskular dapat diserap dengan baik dan mencapai puncak selama 30-60 menit. Aminoglikosida biasanya diberikan melalui cairan infus secara intravena selama 30-60 menit. ${ }^{2}$ Toksisitas aminoglikosida tergantung pada waktu pemberian dan dosis. Banyak penelitian yang telah dilakukan menunjukkan bahwa pemberian aminoglikosida harian dosis tunggal sama efektifnya dan tidak lebih toksik dibandingkan dengan pemberian dosis kecil berulang. ${ }^{2,3}$

Sejumlah kecil aminoglikosida akan tertahan di dalam tubulus proksimal setelah bahan tersebut difiltrasi melalui glomerulus. Aminoglikosida yang tertimbun dalam sel terutama terdapat di dalam vakuolvakuol lisosom dan endosom, dan di dalam kompleks Golgi. Nefrotoksisitas yang diinduksi oleh aminoglokosida secara klinis ditandai oleh gagal ginjal nonoliguri, peningkatan ringan kreatinin serum, dan urin hiperosmolar yang berkembang setelah beberapa hari pemberian bahan tersebut. ${ }^{4}$ Insiden gagal ginjal akut pada manusia karena toksisitas gentamisin kira-kira $15 \% .^{5}$

Secara mikroskopik, toksisitas aminoglikosida terhadap ginjal ditunjukkan oleh adanya nekrosis sel-sel epitel tubulus yang merupakan penyebab utama terjadinya gangguan fungsi ginjal. ${ }^{6-9}$ Penelitian pada tikus Wistar yang diinduksi gentamisin memperlihatkan perubahan morfologik ginjal berupa apoptosis sel-sel epitel tubulus, robeknya membran basalis, proliferasi selsel mesangial, dan menyempitnya ruang Bowman. Robekan membran basalis lebih jelas diperlihatkan melalui pengecatan PAS. ${ }^{10}$

\section{ASPEK FARMAKOLOGIK GENTA- MISIN}

Gentamisin merupakan antibiotik golongan aminoglikosida, yang sering digunakan pada infeksi yang disebabkan oleh bakteri gram negatif. Bahan ini tersedia dalam bentuk gentamisin sulfat ${ }^{2}$ yang tersedia dalam bentuk larutan dalam vial atau ampul $60 \mathrm{mg} / 1,5 \mathrm{ml}, 80 \mathrm{mg} / 2 \mathrm{ml}, 120 \mathrm{mg} / 3$ $\mathrm{ml}$, dan 280mg/ 2ml. Dosis pemberian gentamisin 5-6 $\mathrm{mg} / \mathrm{kgBB} / \mathrm{hari}^{1}$. Semua aminoglikosida akan diserap dengan cepat dari tempat-tempat injeksi secara intramuskuler. Konsentrasi obat dalam plasma mencapai puncaknya sesudah 30-90 menit dan hal ini sama dengan 30 menit sesudah infus intravena selesai. ${ }^{3}$

Aminoglikosida (termasuk gentamisin) merupakan penghambat yang ireversibel terhadap sintesis protein, namun mekanisme kerja dan aktivitas bakterisidalnya belum jelas dipahami. Aktivitas ini berpa difusi pasif melalui pori kanal pada membran luar bakteri. Bahan ini kemudian di transpor secara aktif dari luar membran bakteri masuk ke dalam sitoplasma yang sangat membutuhkan oksigen. Di dalam sel bakteri, aminoglikosida berikatan dengan reseptor pada subunit $30 \mathrm{~S}$ protein ribosom bakteri. Sintesis protein ribosom dihambat oleh aminoglikosida melalui beberapa cara yaitu: mengganggu kompleks inisiasi pembentukan peptida; menyebabkan kesalahan pembacaan mRNA sehingga mengakibatkan penggabungan asam amino yang salah ke dalam peptida; dan menguraikan polisom menjadi monosom yang tak berfungsi. ${ }^{2}$

Umumnya konsentrasi aminoglikosida rendah dalam sekresi dan jaringan. Aminoglikosida tidak berpenetrasi masuk ke dalam sel mast, susunan saraf pusat, atau mata. Konsentrasi tinggi hanya ditemukan pada korteks ginjal serta endolimf dan perilimf telinga bagian dalam; hal ini yang menyokong terjadinya nefrotoksisitas dan ototoksisitas. ${ }^{3}$ Hampir seluruh aminoglikosida diekskresi melalui filtrasi glomerulus 
ginjal dan konsentrasinya dalam urine 50$200 \mathrm{mikogram} / \mathrm{ml}^{3}$

Nefrotoksisitas ringan dan reversibel dapat terjadi pada $5-25 \%$ pasien yang menggunakan obat ini selama 3-5 hari. ${ }^{2}$ Beratnya nefrotoksisitas berhubungan dengan kadar obat yang tinggi dalam plasma. ${ }^{1}$ Insiden gagal ginjal akut disebabkan karena nefrotoksisitas sebesar $15 \%$. Diperkirakan $10 \%$ dari semua kasus gagal ginjal akut disebabkan karena penggunaan antibiotik aminoglikosida. ${ }^{5}$

Pada pemberian aminoglikosida selama beberapa hari, 8-26\% mengalami gangguan ginjal ringan yang hampir selalu reversibel. Toksisitas terjadi karena adanya penimbunan dan retensi aminoglikosida dalam sel-sel epitel tubulus proksimal. Manifestasi awal dari kerusakan pada tempat ini adalah ekskresi ensim (ensimuria) dari lisosomal dan brush border sel epitel tubulus. ${ }^{3,5}$ Setelah beberapa hari terlihat gejala gangguan dalam kemampuan mengkonsentrasi, proteinuria ringan, dan tandatanda cast dan hyaline ringan. Laju filtrasi glomerulus berkurang, dan terlihat tanda insufisiensi ginjal fase non-oligurik disebabkan karena penimbunan aminoglikosida pada porsio distal nefron disertai penurunan sensitivitas epitel duktus kolekting terhadap ADH endogen. Meskipun nekrosis tubulus akut yang berat jarang terjadi, namun tanda yang sering bermakna adalah kreatinin plasma meningkat ringan $(5-20 \mu \mathrm{g} / \mathrm{ml} ; 40$ $175 \mu \mathrm{M}){ }^{3}$ Gangguan fungsi ginjal hampir selalu reversibel setelah pengobatan dihentikan karena sel-sel epitel tubulus proksimal ginjal mempunyai kemampuan beregenerasi. ${ }^{3,5}$ Perubahan-perubahan biokimiawi pada kerusakan sel-sel epitel tubulus dan disfungsi glomerulus masih kurang dipahami. Aminoglikosida menghambat beberapa phospholipase lisosomal seperti aktivitas phosphatidylinositol-specific phospholipase $C$ pada sitosol korteks ginjal dan membran brush border sel epitel tubulus proksimal. Inhibisi dari phospholipase ini merubah jumlah dan komposisi dari plasma dan membran subseluler dalam tubulus proksimal. Perubahan dalam korteks ginjal berhubungan dengan phospholipid menda- hului gejala disfungsi ginjal, Gentamisin menghambat aktifitas dari ensim phospholipase-dependent, Na+-K+-ATPase, dan adenylate cyclase. Selain itu golongan aminoglikosida ini juga mengganggu respiratorik mitokondria. Terjadi disfungsi mitokondria berat dan hal ini mengganggu enersi seluler. Gentamisin juga menghambat pengambilan kalsium dan meningkatkan sitosolik bebas $\left(\mathrm{Ca}^{2+}\right)$. Dalam keadaan ini sekuesterisasi dari aminoglikosida dalam lisosom menyebabkan terbentuknya badan mieloid disebabkan karena degradasi phospholipid, dan integritas membran lisosom terganggu. ${ }^{5}$

Pemberian aminoglikosida dosis terapeutik pada manusia dan hewan (10-20 $\mathrm{mg} / \mathrm{kgBB}$ tipikal untuk tikus di laboratorium) telah menimbulkan perubahan-perubahan yang karakteristik dan nyata pada lisosom sel sel epitel tubulus proksimal. Perubahan ini disertai oleh tanda-tanda disfungsi tubulus, pelepasan brush border dan ensim-ensim lisosomal, penurunan reabsorpsi protein, $\mathrm{K}+, \mathrm{Mg}^{2+}, \mathrm{Ca}^{2+}$, dan glukosa yang difiltrasi, phospholipiduria dan ekskresi cast. Pada manusia hal ini dapat diikuti oleh gangguan fungsi ginjal. ${ }^{4}$

Pemberian gentamisin dosis tinggi (40 $\mathrm{mg} / \mathrm{kgBB}$ atau lebih) dengan cepat menginduksi terjadinya nekrosis korteks ginjal secara luas disertai disfungsi ginjal. Pada keadaan ini terlihat sejumlah besar perubahan struktur metabolik, dan perubahanperubahan pada sel-sel epitel tubulus ginjal berupa disfungsi atau kematian sel. ${ }^{4}$ Sudah banyak diteliti bahwa nekrosis tubulus merupakan hal utama dari toksisitas gentamisin. Ada tiga hipotesis yang telah dikemukakan. Hipotesis pertama membuktikan bahwa toksisitas aminoglikosida berhubungan langsung dengan konsentrasi lokal, dan lisosom merupakan tempat utama dari obat yang masuk ke dalam lisosom. Hipotesis kedua menunjukkan bahwa aminoglikosida menjadi toksik pada saat pertama kali obat itu dilepaskan dari lisosom, pelepasan ini menyebabkan perubahan metabolik maupun kematian sel. Contoh, inhibisi terhadap pernapasan mitokondria dan transpor $\mathrm{Ca}^{2+}$ atau peroksidase lemak, keduanya 
menyebabkan kematian sel. Hipotesis ketiga menyebutkan bahwa penyimpanan obat dalam lisosom secara intrinsik tidak toksik. Simpanan lisosomal dapat melindungi sel dari aminoglikosida yang toksik. ${ }^{4}$

Perubahan morfologik ginjal dengan nekrosis tubuler akut disebabkan karena bahan toksik dan obat seperti gentamisin paling banyak terlihat pada tubulus proksimalis. ${ }^{11}$ Gambaran histologik nekrosis tubuler akut umumnya tidak spesifik. Nekrosis sel epitel tubulus akut disebabkan karena bahan toksik ditandai oleh adanya nekrosis sel-sel epitel tubulus sepanjang tubulus proksimalis. ${ }^{6,9}$ Nekrosis sel-sel epitel tubulus jelas terlihat bilamana sel-sel epitel terlepas ke dalam lumen tubulus dan inti sel menghilang, hal ini terlihat pada kasuskasus yang berat. Perubahan-perubahan pada sel-sel epitel tubulus secara ultrastruktural akan lebih jelas terlihat. Pada beberapa kasus sediaan mikroskopik ginjal dengan menggunakan mikroskop elektron dapat diidentifikasi penyebab dari nefrotoksik. Jika pada kasus ini ditemukan badan-badan myelin ini merupakan tanda bahwa nekrosis disebabkan karena aminoglikosida. ${ }^{9}$ Keracunan yang disebabkan oleh ethylene glycol ditandai oleh degenerasi hidropik, bengkak keruh atau degenerasi vakuoler. Keracunan yang disebabkan oleh karbontetraklorida ditandai oleh penimbunan lemak dalam sel-sel epitel yang cedera (perlemakan sel) diikuti oleh kematian sel. ${ }^{6,9}$ Edema interstisium dapat menyertai nekrosis tubulus tetapi sel-sel radang biasanya tidak ada atau tidak menonjol. Sering terlihat casts hyaline dan debris nekrosis seluler. Membrana basalis tubulus tetap utuh dan regenerasi sel epitel dapat terjadi. Glomerulus dan pembuluh darah biasanya normal. $^{9}$

Salah satu hasil penelitian pada tikus Wistar yang diinduksi gentamisin memperlihatkan sel-sel epitel tubulus nekrosis, apoptosis, membrana basalis tubulus robek, proliferasi sel-sel mesangium, pengecilan ruang Bowman. Dengan pengecatan PAS terlihat jelas robekan pada membrana basalis tubulus. ${ }^{10}$

\section{METODOLOGI PENELITIAN}

Penelitian ini merupakan penelitian eksperimental dengan menggunakan lima ekor tikus Wistar dewasa, berat rata-rata 200g. Penelitian dilakukan di Laboratorium Riset Biomedik dan Laboratorium Patologi Anatomi Fakultas Kedokteran Unsrat Manado. Kelima ekor tikus tersebut dibagi atas tiga kelompok: kelompok I satu ekor tikus tanpa perlakuan, hanya diberikan pelet dan air minum; kelompok II dua ekor tikus yang diberikan gentamisin dengan dosis $60 \mathrm{mg} / \mathrm{kgBB} / \mathrm{hari}$ (10 kali dosis terapi $=10 \mathrm{X} 6 \mathrm{mg} / \mathrm{kg} \mathrm{BB} /$ hari, dihitung sama dengan $0,3 \mathrm{ml} / \mathrm{hari}$ ) yang di injeksi secara intraperitonial selama tujuh hari; dan kelompok III dengan dosis dan cara yang sama diberikan selama 10 hari. Pada hari ke-8 tikus kelompok I dan kelompok II diterminasi, kemudian ginjal difiksasi dengan formalin $10 \%$. Pada hari ke-11 tikus kelompok III diterminasi, kemudian ginjal diambil dengan perlakuan yang sama.

\section{HASIL PENELITIAN}

Ginjal tikus Wistar mempunyai berat rata-rata 1-2 gram, konsistensi kenyal, permukaan licin, dan berwarna coklat muda. Ginjal kelompok I - III tersebut dibelah dua simetris dan dibuat preparat histopatologik dengan pengecatan rutin hematoksilin eosin (HE). Untuk kelompok III, selain pengecatan rutin juga dibuat pengecatan Periodic acid-Schiff (PAS).

Hasil pemeriksaan mikroskopik ginjal tikus Wistar kelompok I (tanpa perlakuan) memperlihatkan arsitektur ginjal normal terdiri dari medula dan korteks dengan tubuli dan glomeruli (Gambar 1). Tubulus tersusun oleh sel-sel epitel kubis, inti bulat ditengah dengan sitoplasma berwarna merah muda homogen.

Hasil pemeriksaan mikroskopik ginjal tikus Wistar kelompok II dengan pemberian gentamisin $0,3 \mathrm{ml} /$ hari secara intraperitonial selama tujuh hari menunjukkan selsel epitel tubuli membengkak (degenerasi hidropik) dimana sel membesar, sitoplasma bervakuola dan granuler, inti bulat di- 
tengah, membran basalis utuh, serta pada beberapa tempat sel-sel epitel tubuli tampak nekrosis dan apoptosis, dengan membran basalis robek (Gambar 2A, B).

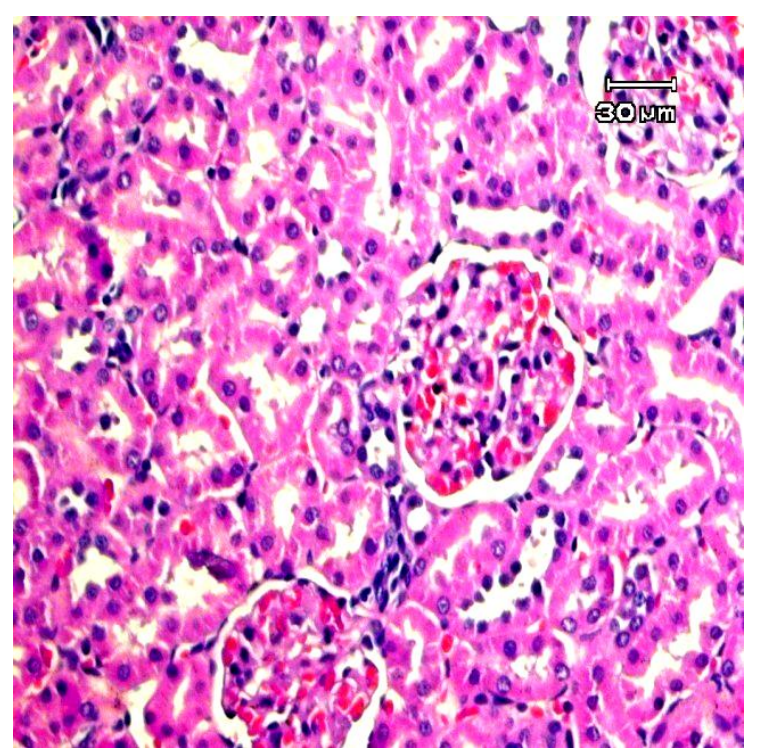

Gambar 1. Gambaran mikroskopik ginjal tikus Wistar kelompok I (tanpa perlakuan) menunjukkan gambaran tubuli dan glomeruli ginjal normal. Sel-sel epitel tubuli berbentuk kubis dengan sitoplasma berwarna merah muda homogen dan membran basalis utuh (pembesaran 200x).
Hasil pemeriksaan mikroskopik ginjal tikus Wistar kelompok III yang diberi gentamisin dosis $0,3 \mathrm{ml}$ dengan cara sama selama 10 hari menunjukkan gambaran yang sama dengan kelompok II (Gambar 3), namun pada kelompok III terlihat juga adanya perlemakan sel dimana sel epitel tubuli membesar, sitoplasma bervakuola sehingga mendorong inti ke tepi (perlemakan makrovesikuler), terutama pada sel-sel epitel tubulus di bagian medula (Gambar 4). Pada sediaan dengan pengecatan PAS tampak sel-sel epitel tubuli dengan pembengkakan sel/degenerasi hidropik, nekrosis, dan apoptosis, juga disertai membran basalis robek (Gambar 5).

\section{BAHASAN}

Pemberian gentamisin pada tikus Wistar dengan dosis $60 \mathrm{mg} / \mathrm{kgBB} / \mathrm{hari}$ atau sama dengan 10 kali dosis terapeutik selama 7-10 hari pada penelitian ini ternyata telah dibuktikan menunjukkan perubahan morfologi pada ginjal tikus perlakuan. Hal ini sesuai dengan yang disebutkan bahwa penggunaan aminoglikosida 10 kali dosis terapeutik dapat menimbulkan efek nefrotoksiknya. $^{12}$

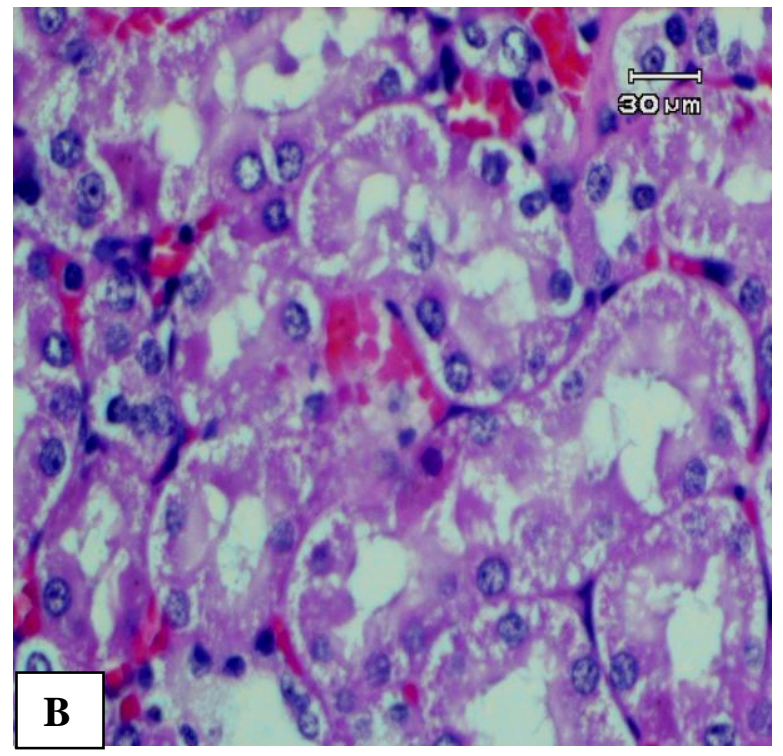

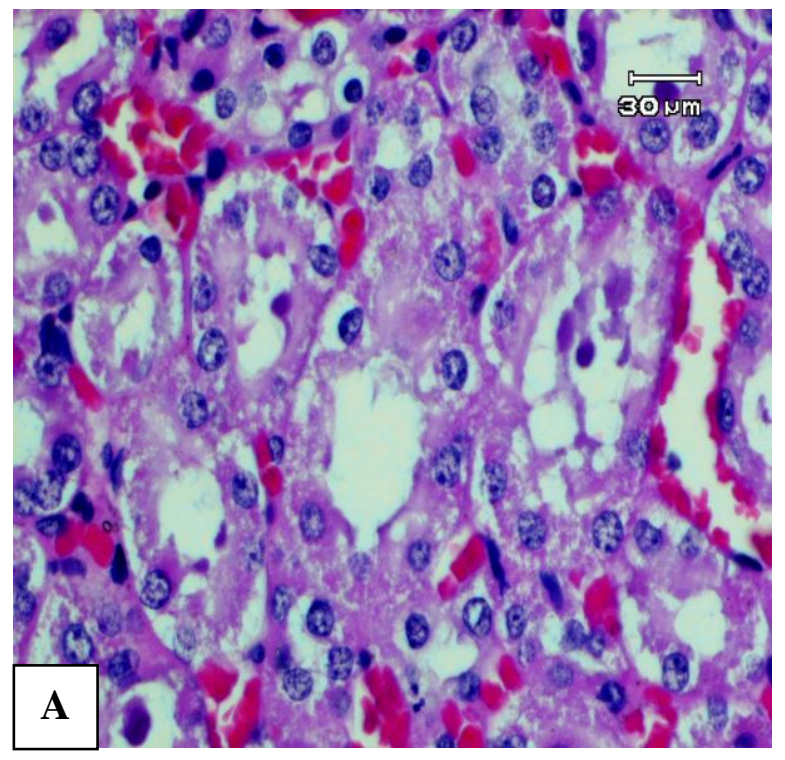

Gambar 2 A dan B. Gambaran mikroskopik ginjal tikus Wistar kelompok II dengan pemberian gentamisin 0,3 ml/hari secara intraperitonial selama tujuh hari. Tampak tubuli membesar, sel-sel epitel membengkak sitoplasma granuler dan sebagian bervakuola, serta sel-sel epitel tubuli nekrosis, inti sel menghilang, sebagian membran basalis tampak utuh tetapi lainnya robek (pembesaran $400 \mathrm{x}$ ). 

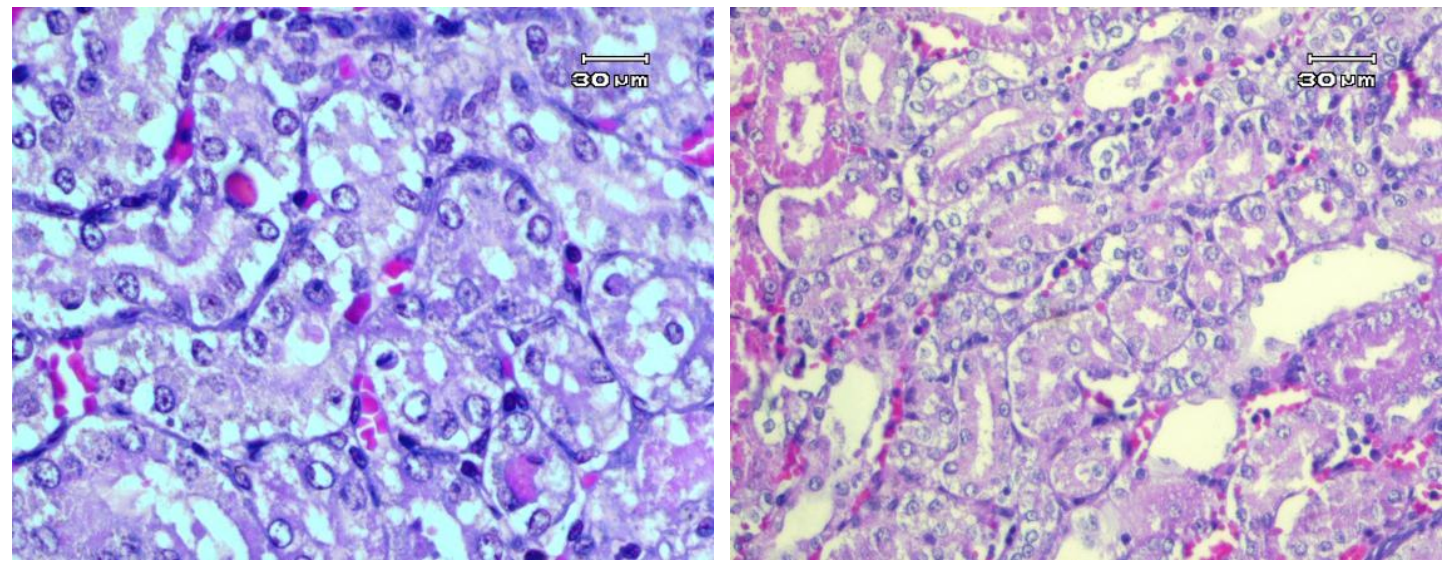

Gambar 3. Gambaran mikroskopik ginjal tikus Wistar kelompok III dengan pemberian gentamisin $0,3 \mathrm{ml} /$ hari secara intraperitonial selama 10 hari. Tampak tubulus membesar, sel-sel epitel membengkak sitoplasma granuler dan sebagian bervakuola, tampak juga sebagian sel nekrosis, inti sel menghilang, membrana basalis utuh. pembesaran 200X dan 400X.
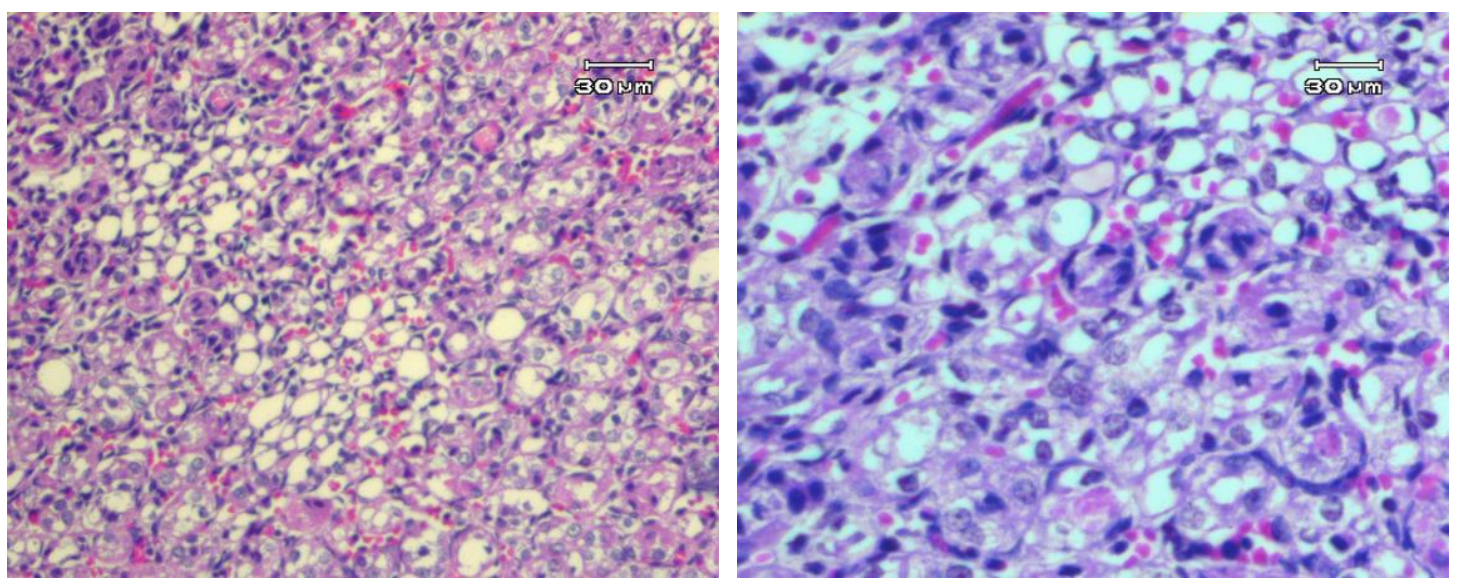

Gambar 4. Gambaran mikroskopik ginjal tikus Wistar kelompok III, tampak sel-sel epitel tubulus dengan lumen ditengahnya, sebagian dari sel epitel dengan sitoplasma bervakuola mendesak inti ketepi (perlemakan makrovesikuler) dan tidak membentuk struktur tubulus normal lagi.

Pembesaran 100X dan 200X.
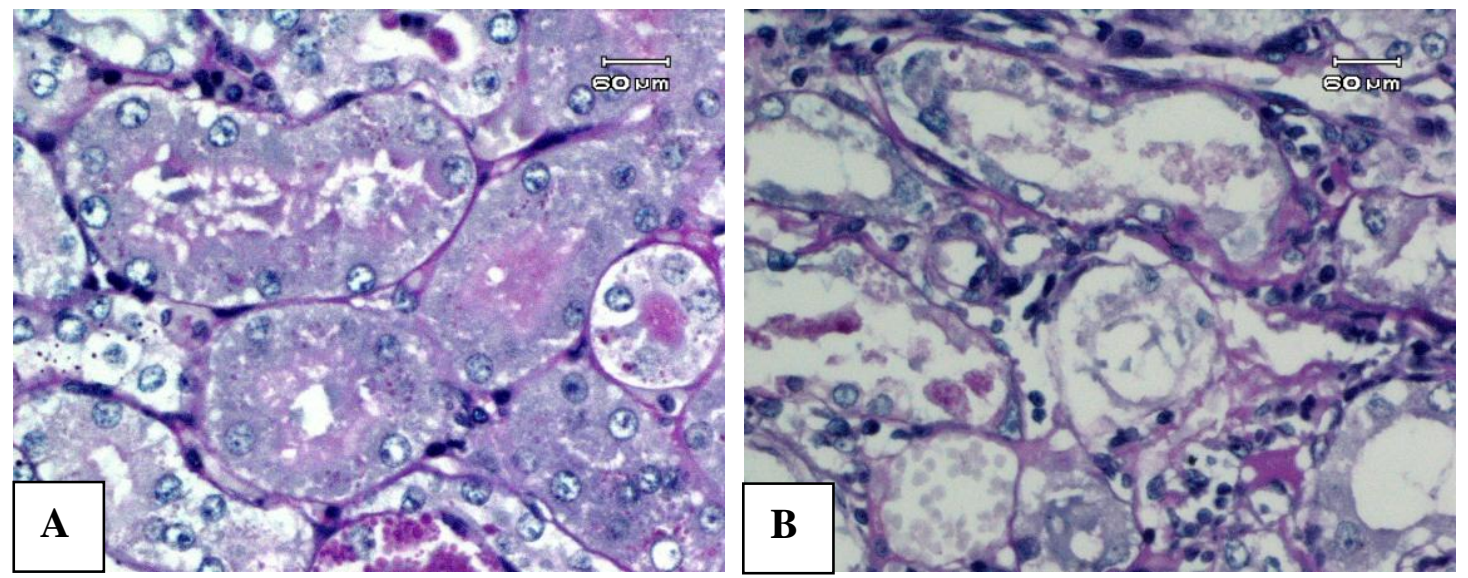

Gambar 5. Gambaran mikroskopik ginjal tikus Wistar kelompok III dengan pengecatan PAS. A. Tampak tubulus membesar, sel-sel epitel membengkak sitoplasma granuler dan sebagian bervakuola, membrana basalis utuh. B.Tampak sel-sel epitel tubulus nekrosis dan apoptosis, membrana basalis robek. Pembesaran $400 \mathrm{X}$. 
Penelitian lain telah membuktikan bahwa pemberian gentamisin pada tikus laboratorium dosis $10-20 \mathrm{mg} / \mathrm{kgBB}$ telah menimbulkan perubahan pada lisosom sel epitel tubulus sehingga mengakibatkan tandatanda disfungsi tubulus dan gangguan fungsi ginjal. Pada dosis $40 \mathrm{mg} / \mathrm{kgBB}$ atau lebih menimbulkan kerusakan lebih hebat dan dengan cepat menginduksi terjadinya nekrosis korteks ginjal secara luas. Pada keadaan ini lebih banyak terlihat perubahan baik dalam struktur metabolik maupun kematian sel. Berdasarkan hipotesis yang telah dijelaskan bahwa toksisitas gentamisin berhubungan langsung dengan konsentrasi lokal dan lisosom adalah tempat utama obat itu di deposit. Pada saat obat itu dilepaskan dari lisosom maka akan terjadi reaksi toksik yakni perubahan metabolik dan kematian sel. ${ }^{4}$

Perubahan morfologi ginjal tikus perlakuan pada penelitian ini dapat dilihat secara mikroskopik pada Gambar 2 dan 3. Umumnya terjadi pembengkakan sel-sel epitel tubulus secara luas, dan sel epitel tubulus yang nekrosis hanya fokus-fokus, inti sel menghilang, dan sebagian besar membrana basalis utuh, namun ada beberapa sudah robek. Membrana basalis yang robek lebih jelas terlihat dengan pengecatan PAS (Gambar 5). Keadaan ini menunjukkan tingkat toksisitas lebih berat. Sebab sesuai kepustakaan menyebutkan bahwa sel-sel epitel tubulus yang nekrosis disebabkan bahan toksik masih memperlihatkan membrana basalis yang utuh. ${ }^{6,8,11}$ Pembengkakan sel epitel tubulus merupakan cedera paling awal dan masih reversibel, hal ini dapat disertai hilangnya brush border dan terlepasnya sel epitel. Sel-sel epitel tubulus membesar disertai vakuol-vakuol dalam sitoplasma, dan sitoplasma kadang granuler. Pembengkakan sel yang terjadi karena obat aminoglikosida disebabkan oleh pelepasan aminoglikosida dari lisosom, menghambat pernapasan mitokondria. ${ }^{4}$ Akibatnya dapat terjadi peningkatan sitosolik $\mathrm{Ca}^{++}$, stress oksidatif, dan peroksidasi lemak, pompa $\mathrm{Na}$ menurun, menyebabkan peningkatan influks $\mathrm{Ca}^{++}$, air, dan $\mathrm{Na}^{+}$masuk dalam sel. Pembengkakan sel masih reversibel, tetapi bilamana keadaan ini berlangsun terus dan melewati suatu titik 'point of no return' maka pembengkakan sel akan beralih menjadi kematian sel. ${ }^{11}$ Pemberian gentamisin selama 10 hari dengan dosis $60 \mathrm{mg} / \mathrm{kgBB} / \mathrm{hari}$ disamping gambaran tersebut diatas juga menunjukkan adanya sel-sel epitel tubulus dengan perlemakan, sel-sel membesar dengan vakuol besar dalam sitoplasme dan inti terdesak ketepi, hal ini disebut perlemakan makrovesikuler seperti terlihat pada gambar 4. Perlemakan pada sel epitel tubulus ginjal juga terjadi karena adanya gangguan pada mitokondria., fosforilasi oksidatif menurun menyebabkan penurunan ATP. Hal ini dapat menyebabkan ribosom terlepas, sintesis protein menurun dan terjadi deposit lemak. ${ }^{11}$

\section{SIMPULAN}

Pemberian gentamisin pada tikus Wistar dengan dosis $60 \mathrm{mg} / \mathrm{kg} \mathrm{BB} / \mathrm{hari}$ selama 7-10 hari menunjukkan edema, nekrosis, dan apoptosis sel epitel tubulus, serta robekan membrana basalis tubulus; dan setelah hari ke-10 juga terlihat perlemakan makrovesikuler. Terjadinya nekrosis sel epitel tubulus dan robekan membrana basalis menunjukkan tingkat toksisitas berat.

\section{DAFTAR PUSTAKA}

1. Istiantoro YH, Gan VHS. Aminoglikosid. In: Gunawan SG, Setiabudy R, Nafrialdi, editors, editor. Farmakologi dan Terapi (Edisi Kelima). Badan Penerbit FKUI, Jakarta: Departemen Farmakologi dan Terapeutik Fakultas Kedokteran Universitas Indonesia, 2007; hal.705-14.

2. Chambers HF. Aminoglikosida \& Spektinomisin In: Katzung Bertram G, editor. Basic and Clinical Pharmacology (Tenth Edition). Jakarta; EGC, 2007; hal.62-71.

3. Mac Dougall C, Chambers HF. Aminoglycosides. In: Brunton LL, Chabner BA, Knollman BC, editors. Goodman \& Gilman's The 
Pharmacological Basis of Therapeutics (Twelfth Edition). New York: Mc.Graw Hill Medical, 2011; p.1505-19.

4. Mingeot-Leclercq MP, Tulkens PM. Aminoglycosides: Nephrotoxicity. Antimicrobial agents and chemotherapy. 1999;43(5):1003-12.

5. Hewitt WR, Goldstein RS, Hook JB. Toxic responses of the kidney. In: Amdes MO, Doull J, Klaassen CD, editors. Casarett and Doull's Toxicology The Basic Science of Poisons. (Fourth Edition). New York: Mc. Graw Hill, Inc., 1991; p.334-79.

6. Rosai J. Rosai and Ackerman's Surgical Pathology Volume II (Ninth Edition). London: Mosby, 2004; p.1159-63.

7. Dehghani F, Namavar MR, Noorafshan, Karbalay-Doust, Esmaeilpour T. Evaluation of the kidney extract on gentamicin induced-nephrotoxixity in rat. Kidney Research Journal. 2011;1(1):24-32.

8. Morin JP, Viotte G, Vandewalle A, Van Hoof F, Tulkens P, Fillastre JP. Gentamicin-induced nephrotoxicity: A cell biology approach. Kidney International. 1980;18:583-90.

9. Guillermo HA, Xin G. Medical diseases of the idney. In: Silverberg SG, DeLellis
RA, Frable WJ, Livolsi VA, Wich MR, editors. Silverberg's Principles and Practice of Surgical Pathology and Cytopathology, Vol 2 (Fourth Edition). Philadelphia: Churchill Livingstone Elsevier, 2006; p.485.

10. De Souza VB, de Oliveira RF, de Lucena HF, Ferreira AAA, Guerra GCB Freitas ML, et al. Gentamicin Induces renal Morphopathology in Wistar Rats. Int. J. Morphol. 2009;27(1):59-63.

11. Alpers CE. The Kidney. In: Kumar V, Abbas AK, Fausto N, Aster JC, editors. Robbins and Cotran Pathologic Basis of Disease (Eigth Edition). Philadelphia: Elsevier Saunders, 2010; p.935-9.

12. Servais H, Mingeot-Leclercq MP, Tulkens PM. Antibiotics induced nephrotoxicity. In: Tarloff JB, Lash LH, editors. Target Organ Toxicology Series, Toxicology of the Kidney (Third Edition). New York: CRC Press, 2005; p.635-84.

13. Uetrecht J, Phillips EJ, Walmsley SL. Antimicrobial agents that affect the synthesis of cellular proteins. In: Kalant H, Grant DM, Mitchell J, editors. Principles of Medical Pharmacology (Seventh Edition). Toronto: Elsevier, 2007; p.697-702. 